\title{
Nucleic Acid Hybridization Studies and Deoxyribonucleic Acid Base Compositions of Anaerobic, Gram-Positive Cocci
}

\author{
VOLKER A. R. HUSS, ${ }^{1}$ HERBERT FESTL, ${ }^{2}$ AND KARL H. SCHLEIFER ${ }^{2 *}$ \\ Institut für Botanik und Pharmazeutische Biologie, Universität Erlangen, D-8520 Erlangen, ${ }^{1}$ and Lehrstuhl für \\ Mikrobiologie, Technische Univesität München, D-8000 München $2,{ }^{2}$ Federal Republic of Germany
}

\begin{abstract}
Deoxyribonucleic acid-deoxyribonucleic acid reassociation and deoxyribonucleic acid-ribosomal ribonucleic acid cistron similarity studies showed that the anaerobic, gram-positive cocci comprise a rather heterogeneous group of bacteria. The deoxyribonucleic acid-ribosomal ribonucleic acid hybridization studies distinguished seven groups. Groups 1 and 2 consisted of Peptostreptococcus magnus and Peptostreptococcus prevotii, respectively. Peptostreptococcus asaccharolyticus ATCC $14963^{\mathrm{T}}(\mathrm{T}=$ type strain) and Peptostreptococcus indolicus ATCC $29427^{\mathrm{T}}$ formed a third group, and Peptostreptococcus asaccharolyticus DSM 20364 together with Hare group VIII strain NCTC 9820 formed group 4. Peptostreptococcus anaerobius DSM 20357 was more closely related to Eubacterium tenue ATCC $25553^{\mathrm{T}}$ and Clostridium lituseburense ATCC $25759^{\mathrm{T}}$ than to any of the other species studied. Peptostreptococcus micros strains DSM $20468^{\mathrm{T}}$ and DSM 20367 together with strains belonging to Hare group IX formed group 6, and group 7 consisted of Peptostreptococcus parvulus DSM $20469^{\mathrm{T}}$. Strains of different Hare groups were all assigned to one of the seven groups or to the genus Staphylococcus (Hare group VIIb strain NCTC 9819) or the genus Streptococcus (Hare group VIa strain NCTC 9806). The anaerobic cocci also have a diversity of murein structures. This is the first report showing that strains belonging to the same species have different murein types.
\end{abstract}

Within the last three decades it has been recognized that anaerobic, gram-positive cocci participate in a large number of infectious diseases and are frequently isolated from mixed infections $(18,20,41,43)$. Although many schemes have been proposed $(5,14,19,30,31)$, the current classification of anaerobic cocci is unsatisfactory, and little is known about the actual relatedness of these organisms despite many studies $(3,6,10-12,24,25)$. In the early 1950 s, Hare and colleagues $(18,39)$ proposed a classification scheme dividing the strains into nine groups, the so-called Hare groups, on the basis of biochemical reactions. Strains belonging to group I were believed to be potential pathogens, whereas the strains of the other groups seemed to have less pathological importance.

Most of the anaerobic, gram-positive cocci can be assigned to Peptococcus or Peptostreptococcus, which, according to Rogosa (31), are distinguished mainly by their different morphologies. Very recently, however, Ezaki et al. (12) proposed, mainly on the basis of the guanine-pluscytosine $(\mathrm{G}+\mathrm{C})$ contents of the deoxyribonucleic acids (DNAs), the transfer of Peptococcus indolicus, Peptococcus asaccharolyticus, Peptococcus prevotii, and Peptococcus magnus to the genus Peptostreptococcus.

The aim of this study was to determine the genetic relatedness of various anaerobic, gram-positive cocci with known murein types by using nucleic acid hybridization techniques.

\section{MATERIALS AND METHODS}

Strains and growth conditions. The strains used in this study are listed in Table 1. Escherichia coli K-12 was grown aerobically in yeast extract-glucose-peptone broth. All other strains were cultivated anaerobically in a medium containing (per liter of distilled water) $10 \mathrm{~g}$ of tryptone (Oxoid Ltd.), 10 $\mathrm{g}$ of yeast extract (Oxoid), $2.5 \mathrm{~g}$ of glucose, $2.5 \mathrm{~g}$ of glycine, $2.5 \mathrm{~g}$ of glutamic acid, $3 \mathrm{~g}$ of sodium acetate, $5 \mathrm{~g}$ of sodium

\footnotetext{
* Corresponding author.
}

chloride, $0.5 \mathrm{~g}$ of L-cysteinium hydrochloride, $5 \mathrm{mg}$ of hemin, $0.5 \mathrm{mg}$ of menadoine (vitamin $\mathrm{K}_{3}$ ), $1 \mathrm{mg}$ of vitamin $\mathrm{K}_{1}$, and $1 \mathrm{ml}$ of Tween 80 (Serva); the $\mathrm{pH}$ was adjusted to 7.2 to 7.4 . The incubation temperature was $37^{\circ} \mathrm{C}$.

DNA and rRNA preparation. DNA was isolated by the method of Huss et al. (22). Ribonucleic acid was labeled in vivo by adding $1 \mathrm{mCi}$ of $\left[5,6-{ }^{3} \mathrm{H}\right]$ uracil $(43.4 \mathrm{Ci} / \mathrm{mmol}$; New England Nuclear Corp.) to $500 \mathrm{ml}$ of growth medium without yeast extract. After the uptake of radioactivity reached a maximum, the cells were harvested, and labeled ribosomal ribonucleic acid (rRNA) was isolated by the method of Stackebrandt et al. (36).

G $+\mathbf{C}$ content of DNA and hybridization experiments. The melting temperature of each DNA was determined with a Gilford model 2600 spectrophotometer, and DNA base composition was calculated by the method of De Ley (7). The renaturation rate method of De Ley et al. (8) or the membrane filter technique was employed for the DNA-DNA hybridization experiments, using the conditions described by Huss et al. (22). DNA-rRNA hybridization studies were carried out by the method of Kilpper-Bälz and Schleifer (26).

Murein types. Murein types were determined by the method of Schleifer and Kandler (33).

\section{RESULTS}

G $+C$ contents and DNA-DNA hybridization. The $G+C$ contents of all of the strains investigated are listed in Table 1. A recent study on the cell wall structures of anaerobic grampositive cocci (40) indicated that these organisms constitute a rather heterogenous group with respect to murein types. We selected strains from groups with different murein types (Table 1) to elucidate the genetic relationships within and among such groups. All of the murein types were examined. The DNA-DNA hybridization data in Table 2 were determined by the membrane filter technique under optimal conditions at $25^{\circ} \mathrm{C}$ below the melting temperature (22). With this method, a degree of binding value ( $D$ value) down to about $10 \%$ is still meaningful for relatedness at the genus 
TABLE 1. List of organisms studied, their murein structures, and the $\mathrm{G}+\mathrm{C}$ contents of their DNAs

\begin{tabular}{|c|c|c|c|c|c|c|}
\hline \multirow{3}{*}{ Organism } & \multirow{3}{*}{ Strain $^{a}$} & \multicolumn{4}{|c|}{ Murein structure } & \multirow{3}{*}{$\begin{array}{l}\mathrm{G}+\mathrm{C} \text { conten } \\
\quad(\mathrm{mol} \%)^{b}\end{array}$} \\
\hline & & \multicolumn{2}{|c|}{ Peptide subunits } & \multirow{2}{*}{$\begin{array}{l}\text { Interpeptide } \\
\text { bridge }\end{array}$} & \multirow{2}{*}{$\begin{array}{l}\text { Refer- } \\
\text { ence }\end{array}$} & \\
\hline & & Position 1 & Position 3 & & & \\
\hline Staphylococcus saccharolyticus & Evans $75-166$ & Ala & Lys & $\mathrm{Gly}_{2}-\mathrm{Ser}-\mathrm{Gly}_{2}$ & 25 & 33.0 \\
\hline Hare group VIIb & NCTC 9819 & Ala & Lys & Gly $_{2}-$ Ser-Gly 2 & 40 & 32.6 \\
\hline Staphylococcus simulans & ATCC $27848^{\mathrm{T}}$ & Ala & Lys & Gly $_{4.9}-$ Ser $_{0.2}$ & 27 & 34.0 \\
\hline Hare group I & NCTC 9801 & Ala & Lys(Orn) & Lys-D-Glu & 40 & 28.3 \\
\hline Hare group III & NCTC 9814 & Ala & Lys(Orn) & Gly $_{5}$ & 38 & 29.2 \\
\hline Streptococcus intermedius & $\operatorname{ATCC} 27335^{\mathrm{T}}$ & Ala & Lys & $\mathrm{Ala}_{2}$ & 40 & 36.5 \\
\hline Hare group VIa & NCTC 9806 & Ala & Lys & $\mathrm{Ala}_{2}$ & 40 & 39.7 \\
\hline Peptostreptococcus anaerobius & DSM 20357 & Ala & Lys & D-Asp & 40 & 34.2 \\
\hline Clostridium lituseburense & ATCC $25759^{\mathrm{T}}$ & Ala & Lys & D-Asp & 36 & 26.7 \\
\hline Peptostreptococcus parvulus & DSM $20469^{\mathrm{T}}$ & Ala & Lys & D-Asp & 40 & 44.0 \\
\hline Peptococcus niger & DSM $20475^{\mathrm{T}}$ & Ala & Lys & D-Asp & 40 & 49.7 \\
\hline \multirow{3}{*}{$\begin{array}{l}\text { Peptostreptococcus indolicus } \\
\text { Peptostreptococcus asaccharolyticus }\end{array}$} & ATCC $29427^{\mathrm{T}}$ & Ala & Orn & D-Glu & 40 & 30.4 \\
\hline & ATCC $14963^{\mathrm{T}}$ & Ala & Orn & D-Glu & 34 & 29.8 \\
\hline & DSM 20364 & Ala & Orn & D-Glu & 23 & 35.6 \\
\hline \multirow[t]{5}{*}{ Peptostreptococcus magnus } & ATCC 14955 & Gly & Lys & Gly & 34 & 32.1 \\
\hline & ATCC $15794^{\mathrm{T}}$ & Gly & Lys & Gly & 40 & 32.4 \\
\hline & DSM 20362 & Gly & Lys & Gly & 40 & 32.1 \\
\hline & DSM 20369 & Gly & Lys & Gly & 40 & 32.3 \\
\hline & ATCC 29328 & Gly & Lys & Gly & 40 & 31.6 \\
\hline Hare group IV & NCTC 9804 & Gly & Lys & Gly & 40 & 32.5 \\
\hline \multirow[t]{2}{*}{ Peptostreptococcus prevotii } & ATCC $9321^{\mathrm{T}}$ & Gly & Lys & D-Glu & 34 & 33.0 \\
\hline & DSM 20358 & Gly & Lys & D-Glu & 40 & 34.0 \\
\hline \multirow[t]{2}{*}{ Hare group IX } & NCTC 9811 & Gly & Lys & D-Asp & 40 & 33.0 \\
\hline & NCTC 9821 & Gly & Lys & D-Asp & 40 & 30.0 \\
\hline \multirow[t]{2}{*}{ Hare group VIII } & NCTC 9810 & Gly & Lys & Gly-D-Asp & 40 & 30.8 \\
\hline & NCTC 9820 & Gly & Lys & Gly-D-Asp & 40 & 34.6 \\
\hline $\begin{array}{l}\text { Peptostreptococcus micros (labeled Pepto- } \\
\text { streptococcus magnus) }\end{array}$ & DSM $20367^{c}$ & Gly & Orn & D-Asp & 40 & 27.4 \\
\hline Peptostreptococcus micros & DSM $20468^{\mathrm{T}}$ & Gly & Orn & D-Asp & 40 & 27.5 \\
\hline Streptococcus sanguis & DSM 20066 & Ala & Lys & None & 33 & 42.6 \\
\hline Eubacterium tenue & ATCC $25553^{\mathrm{T}}$ & Ala & $\mathrm{m}-\mathrm{A}_{2} \mathrm{pm}$ & None & 37 & 26.1 \\
\hline Clostridium butyricum & DSM $552^{\mathrm{T}}$ & Ala & $\mathrm{m}-\mathrm{A}_{2} \mathrm{pm}^{d}$ & None & 37 & 26.8 \\
\hline
\end{tabular}

${ }^{a}$ ATCC, American Type Culture Collection, Rockville, Md.; DSM, Deutsche Sammlung für Mikroorganismen, München, Federal Republic of Germany; Evans, C. A. Evans, University of Washington, Seattle; NCTC, National Collection of Type Cultures, London, England.

${ }^{b}$ Escherichia coli $\mathrm{K}-12(\mathrm{G}+\mathrm{C}$ content, $51.7 \mathrm{~mol} \%$ [7]) was used as the reference.

${ }^{c}$ This strain is not listed in the latest catalog of the Deutsche Sammlung für Mikroorganismen, but it is still available (N. Weiss, personal communication).

${ }^{d} \mathrm{~m}-\mathrm{A}_{2} \mathrm{pm}$, meso-Diaminopimelic acid.

level, whereas the renaturation rate method (Tables 3 through 6) has no relevance below a $D$ value of $25 \%$ (22). Therefore, $D$ values in this range are reported as $<25 \%$.

As shown in Table 2, Hare group VIIb strain NCTC 9819 is a Staphylococcus saccharolyticus strain $(24,25)$, whereas Hare group III strain NCTC 9814 showed no detectable relatedness to Staphylococcus saccharolyticus or Staphylococcus simulans despite a pentaglycine interpeptide bridge in its murein, which is characteristic of many staphylococci (32). Peptostreptococcus prevotii ATCC $9321^{\mathrm{T}}$ ( $\mathrm{T}=$ type strain) and Peptostreptococcus prevotii DSM 20358 are not identical but are closely related (Table 2). The DNAs of both of these strains showed no significant hybridization with the DNA of Peptostreptococcus asaccharolyticus ATCC $14963^{\mathrm{T}}$ or the DNA of Staphylococcus saccharolyticus (Table 2).

The comparative physiological and biochemical investigations of Barnes et al. (1) with representatives of Hare group VIa and Streptococcus intermedius revealed a close relationship, which we confirmed by finding a $D$ value of $53 \%$ between the DNAs of strain NCTC 9806 and Streptococcus intermedius ATCC $27335^{\mathrm{T}}$.

Various strains of Peptostreptococcus magnus, as well as Hare group IV, have the same murein type (Table 1). Hybridization values ( $D$ values) of 55 to $74 \%$ showed that 
TABLE 2. DNA-DNA hybridization studies with Peptostreptococcus prevotii, Peptostreptococcus asaccharolyticus, staphylococci, and representatives of Hare groups VIIb and III $^{a}$

\begin{tabular}{|c|c|c|c|c|c|c|c|}
\hline \multirow[b]{2}{*}{ Source of $\left[{ }^{3} \mathrm{H}\right] \mathrm{DNA}$} & \multicolumn{7}{|c|}{$D$ value (\%) with filter-bound DNA from: } \\
\hline & $\begin{array}{l}\text { Peptostrep- } \\
\text { tococcus } \\
\text { prevotii } \\
{\text { ATCC } 9321^{\mathrm{T}}}\end{array}$ & $\begin{array}{l}\text { Peptostrep- } \\
\text { tococcus } \\
\text { prevotii } \\
\text { DSM } 20358\end{array}$ & $\begin{array}{c}\text { Peptostrep- } \\
\text { tococcus } \\
\text { asaccharolyticus } \\
\text { ATCC } 14963\end{array}$ & $\begin{array}{l}\text { Hare group } \\
\text { Vllb strain } \\
\text { NCTC } 9819\end{array}$ & $\begin{array}{c}\text { Staphylococcus } \\
\text { saccharolyticus } \\
\text { Evans } 75-166\end{array}$ & $\begin{array}{l}\text { Staphylococcus } \\
\text { simulans } \\
\text { ATCC } 27848^{\mathrm{T}}\end{array}$ & $\begin{array}{l}\text { Hare group } \\
\text { III strain } \\
\text { NCTC } 9814\end{array}$ \\
\hline $\begin{array}{l}\text { Peptostreptococcus prevotii ATCC } \\
9321^{\mathrm{T}}\end{array}$ & 100 & 49 & 9 & 7 & 4 & $\mathrm{ND}^{b}$ & ND \\
\hline $\begin{array}{l}\text { Peptostreptococcus prevotii DSM } \\
\quad 20358\end{array}$ & 50 & 100 & 8 & 6 & 5 & ND & ND \\
\hline $\begin{array}{l}\text { Peptostreptococcus asaccharolyticus } \\
\text { ATCC } 14963^{\mathrm{T}}\end{array}$ & 9 & 8 & 100 & 6 & 6 & ND & ND \\
\hline Hare group VIIb strain NCTC 9819 & 6 & 4 & 6 & 100 & 92 & 10 & 2 \\
\hline $\begin{array}{l}\text { Staphylococcus saccharolyticus } \\
\text { Evans } 75-166\end{array}$ & 6 & 5 & 5 & 95 & 100 & 21 & ND \\
\hline $\begin{array}{l}\text { Staphylococcus saccharolyticus } \\
\text { ATCC } 14953^{\mathrm{T}}\end{array}$ & 5 & 6 & 7 & ND & 100 & 24 & ND \\
\hline $\begin{array}{l}\text { Staphylococcus simulans ATCC } \\
27848^{\mathrm{T}}\end{array}$ & ND & ND & ND & 13 & 12 & 100 & 3 \\
\hline Hare group III strain NCTC 9814 & ND & ND & ND & 2 & 4 & 3 & 100 \\
\hline
\end{tabular}

${ }^{a}$ The levels of hybridization on membrane filters were determined under optimal conditions (25 ${ }^{\circ} \mathrm{C}$ below the melting temperature [23]).

${ }^{b}$ ND, Not determined.

these organisms form a rather homogenous group (Table 3).

Four different types of peptidoglycan have been reported for strains labeled Peptostreptococcus prevotii and members of Hare groups I, III, and VIII (40). Nevertheless, two strains (strains NCTC 9801 [Hare group I] and NCTC 9814 [Hare group III]) showed a high $D$ value $(77 \%)$. All of the other homology values within this group were near the limit of sensitivity of the hybridization method used (Table 4). The significance of these values is demonstrated by the results of the DNA-rRNA hybridization studies (see below).

Peptostreptococcus as accharolyticus ATCC $14963^{\mathrm{T}}$ is related to Peptostreptococcus indolicus ATCC $29427^{\mathrm{T}}$ (D value, $38 \%$ ) whereas no significant DNA homology has been observed with strain DSM 20364 (also labeled Peptostrep-

TABLE 3. DNA-DNA hybridization studies with the Peptostreptococcus magnus group, using the renaturation rate method

\begin{tabular}{|c|c|c|c|c|c|c|}
\hline \multirow{3}{*}{ Strain } & \multicolumn{6}{|c|}{$D$ value $(\%)$ with: } \\
\hline & \multicolumn{4}{|c|}{$\begin{array}{l}\text { Peptostreptococcus magnus } \\
\text { strains }\end{array}$} & \multicolumn{2}{|c|}{$\begin{array}{l}\text { Hare group IV } \\
\text { strains }\end{array}$} \\
\hline & $\begin{array}{l}\text { ATCC } \\
15794^{\mathrm{T}}\end{array}$ & $\begin{array}{l}\text { DSM } \\
20362\end{array}$ & $\begin{array}{l}\text { DSM } \\
20369\end{array}$ & $\begin{array}{l}\text { ATCC } \\
29328\end{array}$ & $\begin{array}{c}\text { NCTC } \\
9804\end{array}$ & $\begin{array}{l}\text { NCTC } \\
9815\end{array}$ \\
\hline $\begin{array}{l}\text { Peptostreptococcus } \\
\quad \text { magnus ATCC } \\
14955\end{array}$ & 65 & 62 & 67 & 56 & 63 & 65 \\
\hline $\begin{array}{l}\text { Peptostreptococcus } \\
\text { magnus ATCC } \\
15794^{\mathrm{T}}\end{array}$ & & 63 & 69 & 59 & 71 & 74 \\
\hline $\begin{array}{l}\text { Peptostreptococcus } \\
\quad \text { magnus DSM } \\
20369\end{array}$ & & & 70 & 63 & 65 & 65 \\
\hline $\begin{array}{l}\text { Peptostreptococcus } \\
\quad \text { magnus DSM } \\
20362\end{array}$ & & & & 55 & 70 & 73 \\
\hline $\begin{array}{l}\text { Peptostreptococcus } \\
\quad \text { magnus ATCC } \\
29328\end{array}$ & & & & & 61 & 55 \\
\hline $\begin{array}{l}\text { Hare group IV } \\
\text { strain NCTC } \\
9804\end{array}$ & & & & & & 74 \\
\hline
\end{tabular}

tococcus asaccharolyticus) (Table 5) or four clinical isolates that are highly related to strain DSM 20364 (22; data not shown). Hare group VIII strain NCTC 9820, which has a different type of murein (Table 1), also belongs to this group (Table 5).

Strain DSM 20367 (labeled Peptostreptococcus magnus) has been identified as Peptostreptococcus micros (40). This was confirmed by the $D$ value $(81 \%)$ between the DNAs of these organisms (Table 6). Strains belonging to Hare group IX also are related to Peptostreptococcus micros ( $D$ values, 38 to $57 \%$ ); the significance of the $28 \%$ DNA homology between Peptostreptococcus parvulus and Peptostreptococcus anaerobius was tested by DNA-rRNA hybridization (see below).

None of the other DNA-DNA hybridization experiments performed between members of the different groups listed in Table 1, including Peptococcus niger DSM $20475^{\mathrm{T}}$, indicated any significant relatedness $(D$ values, $<25 \%$ [data not shown]).

DNA-rRNA hybridization. Since the cistrons coding for rRNAs have changed considerably less during evolution than the rest of the genomes $(15,42)$, DNA-rRNA hybridization studies are more useful for elucidating genetic relationships at the higher levels (i.e., genus or family level) than DNA-DNA comparisons (29). In contrast to DNA-DNA reassociation experiments, the $D$ value between DNA and rRNA is not necessarily a relevant criterion for determining

TABLE 4. DNA-DNA hybridization studies with Peptostreptococcus prevotii DSM 20358 and Hare groups I, III and VIII (strain NCTC 9810), using the renaturation rate method

\begin{tabular}{lccc}
\hline \multirow{2}{*}{ Strain } & \multicolumn{3}{c}{$D$ value (\%) with: } \\
\cline { 2 - 4 } & $\begin{array}{c}\text { Hare group } \\
\text { I strain } \\
\text { NCTC 9801 }\end{array}$ & $\begin{array}{c}\text { Hare group } \\
\text { III strain } \\
\text { NCTC 9814 }\end{array}$ & $\begin{array}{c}\text { Hare group } \\
\text { VIII strain } \\
\text { NCTC 9810 }\end{array}$ \\
\hline $\begin{array}{l}\text { Peptostreptococcus prevotii } \\
\text { DSM 20358 }\end{array}$ & 28 & 26 & $<25$ \\
$\begin{array}{l}\text { Hare group I strain NCTC } \\
\quad \text { 9801 }\end{array}$ & & 77 & 25 \\
Hare group III strain & & & 26 \\
$\quad$ NCTC 9814 & & & \\
\hline
\end{tabular}


TABLE 5. DNA-DNA hybridization studies with Peptostreptococcus indolicus, Peptostreptococcus asaccharolyticus, and Hare group VIII (strain NCTC 9820), using the renaturation rate method

\begin{tabular}{lccc}
\hline & \multicolumn{3}{c}{$D$ value (\%) with: } \\
\cline { 2 - 4 } Strain & ATCC & DSM & $\begin{array}{r}\text { Hare group } \\
\text { VIII strain } \\
\text { NCTC 9820 }\end{array}$ \\
\hline $\begin{array}{l}14963^{\mathrm{T}} \\
\text { Peptostreptococcus indolicus ATCC }\end{array}$ & 38 & $<25$ & $<25$ \\
$\begin{array}{c}\text { 29427 } \\
\text { Peptostreptococcus asaccharolyticus } \\
\text { ATCC 14963 }\end{array}$ & & $<25$ & $<25$ \\
$\begin{array}{l}\text { Peptostreptococcus asaccharolyticus } \\
\text { DSM 20364 }\end{array}$ & & 54 \\
\hline
\end{tabular}

relationships among bacteria, since rRNA cistrons can be found in different copy numbers $(29,44,45)$, A better criterion is the thermal stability of DNA-rRNA hybrids (9). The difference in melting points between homologous and heterologous hybrids $\left[\Delta T_{m(e)}\right]$ was used to construct an average linkage dendrogram, which shows the relationships within the anaerobic, gram-positive cocci with respect to the thermal stability of DNA-rRNA hybrids (Fig. 1). The thermal stability values are listed in Table 7.

\section{DISCUSSION}

Figure 1 shows that the anaerobic, gram-positive cocci examined in this study can be divided into seven groups. The first group comprises strains of Peptostreptococcus magnus, and the second group consists of Peptostreptococcus prevotii and three strains belonging to different Hare groups. The third group is made up of Peptostreptococcus asaccharolyticus ATCC $14963^{\mathrm{T}}$ and Peptostreptococcus indolicus, which have a DNA homology value ( $D$ value) of $38 \%$. Peptostreptococcus asaccharolyticus DSM 20364 and Hare group VIII strain NCTC 9820 form a separate group. The latter two groups are characterized by having exclusively class I fructose-1,6-biphosphate aldolase, in contrast to all of the other peptostreptococci examined, which possess class II fructose-1,6-biphosphate aldolase (13). Class I fructose-1,6-biphosphate aldolase of the Peptostreptococcus asaccharolyticus type has otherwise been found only in staphylococci (13, 17). Our results are not in complete agreement with those of Ezaki (10) and Ezaki et al. (12); we found a DNA homology value ( $D$ value) of $38 \%$ ( $40 \%$ when the membrane filter method was used) between Peptostreptococcus asaccharolyticus ATCC $14963^{\mathrm{T}}$ and Peptostreptococcus indolicus ATCC $29427^{\mathrm{T}}$, in contrast to $D$ values of 3 to $8 \%(10)$ and $15 \%$ (12). These two strains also differed by about 3 to 4 mol\% in their $\mathrm{G}+\mathrm{C}$ contents compared with our results. The results of the cell wall analysis of our strains agreed with the

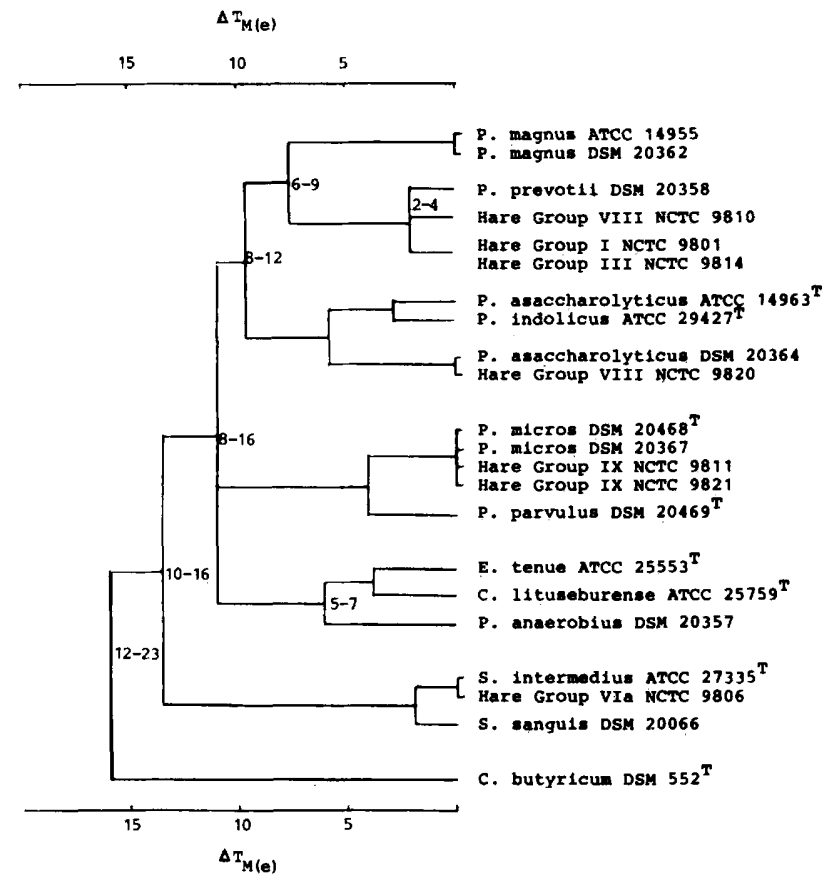

FIG. 1. Dendrogram based on DNA-rRNA hybridization studies of anaerobic, gram-positive bacteria. The $\Delta T_{m(e)}$ values of DNArRNA hybrids (see Table 7) were used to construct an average linkage dendrogram. The numbers at the branches reflect the spreading of $\Delta T_{m(e)}$ values between groups. The brackets indicate DNA homology values ( $D$ values) of more than $30 \%$. Streptococcus intermedius and Peptostreptococcus micros DSM $20468^{\mathrm{T}}$ were included on the basis of their high DNA-DNA homology values with Hare group IVa strain NCTC 9806 (53\%) and Peptostreptococcus micros DSM 20367 (81\%), respectively.

murein types described by Schleifer and Nimmermann (34) and Weiss (40). This indicates that we did not use wrong strains. In addition, Ezaki et al. (12) found a distinct relationship between Peptostreptococcus asaccharolyticus ATCC $14963^{\mathrm{T}}$ and Peptostreptococcus prevotii ATCC 9321 (D value, $46 \%$ ). Our data and those of Kilpper (R. Kilpper, Ph.D. thesis, Technical University of Munich, Munich, Federal Republic of Germany, 1980) do not show any DNA homology $(D$ value, $<10 \%$ ) and very low DNA-rRNA similarity $\left(\Delta T_{m(e)}, 13^{\circ} \mathrm{C}\right)$ between these species.

Peptostreptococcus anaerobius DSM 20357 is only remotely related to the other anaerobic, gram-positive cocci. On the other hand, it is closely related to Eubacterium tenue and Clostridium lituseburense. This unusual relationship to morphologically different sporeforming organisms (the dif-

TABLE 6. DNA-DNA hybridization studies with Peptostreptococcus micros, Peptostreptococcus parvulus, Peptostreptococcus anaerobius, and Hare group IX, using the renaturation method

\begin{tabular}{|c|c|c|c|c|c|}
\hline \multirow{3}{*}{ Strain } & \multicolumn{5}{|c|}{$D$ value $(\%)$ with: } \\
\hline & \multirow{2}{*}{$\begin{array}{c}\text { Peptostreptococcus } \\
\text { micros } \\
\text { DSM } 20468^{\mathrm{T}}\end{array}$} & \multicolumn{2}{|c|}{ Hare group IX strains } & \multirow{2}{*}{$\begin{array}{c}\text { Peptostreptococcus } \\
\text { parvulus } \\
\text { DSM } 20469^{\mathrm{T}}\end{array}$} & \multirow{2}{*}{$\begin{array}{c}\text { Peptostreptococcus } \\
\text { anaerobius } \\
\text { DSM } 20357\end{array}$} \\
\hline & & NCTC 9811 & NCTC 9821 & & \\
\hline Peptostreptococcus micros DSM 20367 & 81 & 39 & 57 & 29 & $<25$ \\
\hline Peptostreptococcus micros DSM $20468^{\mathrm{T}}$ & & 38 & 55 & 30 & $<25$ \\
\hline Hare group IX strain NCTC 9811 & & & 76 & 31 & $<25$ \\
\hline Hare group IX strain NCTC 9821 & & & & 26 & $<25$ \\
\hline Peptostreptococcus parvulus DSM $20469^{\mathrm{T}}$ & & & & & 28 \\
\hline
\end{tabular}


TABLE 7. DNA-rRNA hybridization studies of anaerobic gram-positive bacteria ${ }^{a}$

\begin{tabular}{|c|c|c|c|c|c|c|c|}
\hline \multirow[b]{2}{*}{ Source of filter-bound DNA } & \multicolumn{7}{|c|}{$\Delta T_{m(e)}{ }^{b}\left({ }^{\circ} \mathrm{C}\right)$ with $\left[{ }^{3} \mathrm{H}\right] \mathrm{rRNA}$ from: } \\
\hline & $\begin{array}{l}\text { Peptostrepto- } \\
\text { coccus asaccha- } \\
\text { rolyticus } \\
\text { ATCC } 14963^{\mathrm{T}}\end{array}$ & $\begin{array}{l}\text { Peptostrepto- } \\
\text { coccus magnus } \\
\text { DSM } 20362\end{array}$ & $\begin{array}{c}\text { Peptostrepto- } \\
\text { coccus } \\
\text { prevotii } \\
\text { DSM } 20358\end{array}$ & $\begin{array}{l}\text { Peptostrepto- } \\
\text { coccus parvulus } \\
\text { DSM } 20469\end{array}$ & $\begin{array}{c}\text { Clostridium } \\
\text { lituse- } \\
\text { burense }\end{array}$ & $\begin{array}{l}\text { Eubac- } \\
\text { terium } \\
\text { tenue }\end{array}$ & $\begin{array}{l}\text { Strepto- } \\
\text { coccus } \\
\text { sanguis }\end{array}$ \\
\hline $\begin{array}{l}\text { Peptostreptococcus asaccharolyticus } \\
\text { ATCC } 14963^{\mathrm{T}}\end{array}$ & $0(73.5)^{b}$ & 8.3 & 11.1 & 12.1 & 17.6 & $\mathrm{ND}^{c}$ & ND \\
\hline $\begin{array}{l}\text { Peptostreptococcus indolicus ATCC } \\
29427^{\mathrm{T}}\end{array}$ & 3.5 & 9.5 & 11.7 & ND & 18.2 & 12.6 & ND \\
\hline $\begin{array}{l}\text { Peptostreptococcus asaccharolyticus } \\
\text { DSM } 20364\end{array}$ & 5.6 & 8.2 & 8.7 & 10.8 & 14.2 & ND & 14.0 \\
\hline Hare group VIll strain NCTC 9820 & 5.5 & 7.8 & 9.1 & ND & 15.9 & 15.0 & ND \\
\hline $\begin{array}{l}\text { Peptostreptococcus magnus DSM } \\
20362\end{array}$ & 8.3 & $0(78.8)$ & 6.5 & ND & 15.3 & 9.4 & ND \\
\hline $\begin{array}{l}\text { Peptostreptococcus magnus ATCC } \\
14955\end{array}$ & 9.6 & 0.1 & ND & 11.3 & 17.7 & 10.0 & 14.8 \\
\hline Hare group IX strain NCTC 9811 & 10.6 & 8.2 & 11.5 & ND & 16.1 & 15.5 & ND \\
\hline Hare group IX strain NCTC 9821 & 9.0 & 7.7 & 9.6 & ND & 14.2 & 14.5 & ND \\
\hline $\begin{array}{l}\text { Peptostreptococcus prevotii DSM } \\
20358\end{array}$ & 10.1 & 9.0 & $0(74.8)$ & 12.4 & ND & 11.7 & 15.1 \\
\hline Hare group VIII strain NCTC 9810 & 9.5 & 7.7 & 2.3 & ND & 11.5 & 15.4 & ND \\
\hline Hare group I strain NCTC 9801 & ND & 7.4 & 2.6 & 7.8 & 16.8 & 13.6 & ND \\
\hline Hare group III strain NCTC 9814 & 8.6 & 7.4 & 3.7 & ND & 16.8 & 15.2 & ND \\
\hline $\begin{array}{l}\text { Peptostreptococcus parvulus DSM } \\
20469^{\mathrm{T}}\end{array}$ & 12.9 & 13.8 & 16.2 & $0(73.8)$ & ND & 15.8 & 14.3 \\
\hline $\begin{array}{l}\text { Peptostreptococcus micros DSM } \\
20367\end{array}$ & 7.9 & 8.2 & 9.6 & 4.0 & ND & 12.3 & 15.3 \\
\hline $\begin{array}{l}\text { Clostridium lituseburense ATCC } \\
25759^{\mathrm{T}}\end{array}$ & 13.0 & 9.8 & 12.5 & ND & $0(79.1)$ & 3.1 & ND \\
\hline Eubacterium tenue ATCC $25553^{\mathrm{T}}$ & 9.4 & 10.6 & 9.7 & ND & 4.4 & $0(79.2)$ & ND \\
\hline $\begin{array}{l}\text { Peptostreptococcus anaerobius } \\
\text { DSM } 20357\end{array}$ & 10.8 & 10.7 & 11.0 & ND & 6.5 & 5.0 & 15.3 \\
\hline Clostridium butyricum DSM $552^{\mathrm{T}}$ & 14.2 & 12.2 & 16.2 & ND & 23.0 & 12.7 & ND \\
\hline Streptococcus sanguis DSM 20066 & ND & ND & ND & ND & ND & ND & $0(77.5)$ \\
\hline Hare group VIa strain NCTC 9806 & 11.8 & 10.8 & 10.1 & 11.8 & 13.2 & ND & 1.6 \\
\hline
\end{tabular}

${ }^{a}$ The preparations were incubated in double standard saline citrate containing $20 \%$ formamide at $50^{\circ} \mathrm{C}$.

${ }^{b}$ The numbers in parentheses are the temperatures at which $50 \%$ of the bound rRNA $\left(\mathrm{T}_{m(e)}\right)$ was eluted from the filters for the homologous hybrids.

"ND, Not determined.

ference in $\mathrm{G}+\mathrm{C}$ contents is about $8 \mathrm{~mol} \%$ ) has been confirmed by comparative sequence analyses of $16 \mathrm{~S}$ rRNAs $(37$; W. Ludwig, Ph.D. thesis, Technical University of Munich, Munich, Federal Republic of Germany, 1981). The $S_{\mathrm{AB}}$ values (oligonucleotide similarities) of about 0.75 among these strains are equivalent to the values within the welldefined genus Staphylococcus (28). This surprising similarity of RNAs between representatives of the clostridia and organisms which would not, if classical criteria were used, be regarded as belonging to the clostridia, is not an isolated case (16). Clostridium butyricum, as a representative species and the type species of the genus Clostridium, shows no relationship to $C$. lituseburense or any of the other strains examined in this study.

Our data support the relationship of the anaerobic aerotolerant species Streptococcus intermedius (21) to other members of the genus Streptococcus (e.g., Streptococcus sanguis). Peptostreptococcus parvulus also has been described as belonging to the genus Streptococcus on the basis of increased fermentative ability and production of lactic acid when growth is stimulated by Tween 80 (3). However, our hybridization data do not indicate any relationship at the genus level. DNA-rRNA hybridization studies showed a high $\Delta T_{m(e)}\left(11\right.$ to $\left.14^{\circ} \mathrm{C}\right)$ between Peptostreptococcus parvulus DSM 20469 and Streptococcus intermedius NCTC 9806, as well as Streptococcus sanguis DSM 20066. Peptostrep- tococcus parvulus also is not related to Streptococcus pyogenes NCTC 8198, the type species of the genus Streptococcus (R. Kilpper-Bälz, personal communication).

Peptococcus niger, the type species of the genus Peptococcus, was not included in our DNA-rRNA hybridization studies because of difficulties in preparing high-molecularweight DNA or radioactively labeled rRNA. With a $\mathrm{G}+\mathrm{C}$ content of about $50 \mathrm{~mol} \%$, this species is certainly not related to the other anaerobic, gram-positive cocci $(\mathrm{G}+\mathrm{C}$ contents, 30 to $36 \mathrm{~mol} \%$ ). However, Peptococcus niger and Peptostreptococcus parvulus both possess the same type of murein and have similar $\mathrm{G}+\mathrm{C}$ contents (Table 1). Further study will be necessary to determine the relatedness of these two species.

All of the strains of the different Hare groups which we examined can be assigned to existing species or genera. However, Hare group VIII was not uniform in terms of fermentation products (40) or hybridization data. On the other hand, Hare group I strain NCTC 9801 and group III strain NCTC 9814, which have a DNA homology value $(D$ value) of $77 \%$, should belong to one species (2). Together with Hare group VIII strain NCTC 9810 these two strains are related to Peptostreptococcus prevotii DSM $20358\left[\Delta T_{m(e)}, 2\right.$ to $4^{\circ} \mathrm{C}$. Another strain of Hare group VIII (strain NCTC 9820 ), which has a $D$ value of $54 \%$, can be regarded as a subspecies of Peptostreptococcus asaccharolyticus. Both 
TABLE 8. Diversity of murein structures of some closely related anaerobic cocci

\begin{tabular}{|c|c|c|c|c|c|}
\hline \multirow{3}{*}{ Strain(s) } & \multicolumn{3}{|c|}{ Murein structure } & \multirow{3}{*}{$\begin{array}{c}D \\
\text { value } \\
(\%)^{a}\end{array}$} & \multirow{3}{*}{$\begin{array}{l}\Delta T_{m(e)} \\
\left({ }^{\circ} \mathrm{C}\right)^{b}\end{array}$} \\
\hline & \multicolumn{2}{|c|}{ Peptide subunit } & \multirow{2}{*}{$\begin{array}{l}\text { Interpeptide } \\
\text { bridge }\end{array}$} & & \\
\hline & Position 1 & Position 3 & & & \\
\hline Peptostreptococcus micros DSM $20468^{\mathrm{T}}$ & Gly & Orn & $\leftarrow \mathrm{D}-\mathrm{Asp}$ & $38-57$ & $\overline{\mathrm{ND}^{c}}$ \\
\hline Hare group IX strains NCTC 9811 and NCTC 9821 & Gly & Lys & $\leftarrow$ D-Asp & $38-57$ & $\mathrm{ND}$ \\
\hline Hare group I strain NCTC 9801 & Ala & Lys(Orn) & Lys-D-Glu & 77 & $2-4$ \\
\hline Hare group III strain NCTC 9814 & Ala & Lys(Orn) & Gly $_{5}$ & 77 & $2-4$ \\
\hline Peptostreptococcus prevotii DSM 20358 & Gly & Lys & D-Glu & 25 & $2-4$ \\
\hline Hare group VIII strain NCTC 9810 & Gly & Lys & Gly-D-Asp & 25 & $2-4$ \\
\hline Peptostreptococcus asaccharolyticus DSM 20364 & Ala & Orn & D-Glu & 54 & ND \\
\hline Hare group VIII strain NCTC 9820 & Gly & Lys & Gly-D-Asp & 54 & ND \\
\hline
\end{tabular}

${ }^{a}$ DNA homology.

${ }^{b}$ See Table 7.

c ND, Not determined.

strains of Hare group IV are Peptostreptococcus magnus (Table 3), and the strains of group IX are related to Peptostreptococcus micros at the species or subspecies level.

Apart from the Peptococcaceae, relationships could be demonstrated with other families. Hare group VIIb strain NCTC 9819 is a strain of Staphylococcus saccharolyticus, an anaerobic member of the genus Staphylococcus $(24,25)$. Finally, Hare group VIa strain NCTC 9806 is related to Streptococcus intermedius ATCC $27335^{\mathrm{T}}$.

From our results and previous nucleic acid hybridization studies $(11,12,23,24)$, we concluded that the anaerobic, gram-positive cocci form a heterogenous group. The $\mathrm{G}+\mathrm{C}$ contents of the DNAs of the type strains of Peptococcus niger (49 to $51 \mathrm{~mol} \%$ ) and Peptostreptococcus parvulus (44 to $46 \mathrm{~mol} \%$ ) differ significantly from those of other anaerobic, gram-positive cocci ( 27 to 35 mol\%). However, the proposed transfer of Peptostreptococcus parvulus to the genus Streptococcus could not be confirmed by our results.

On the basis of differences in the $\mathrm{G}+\mathrm{C}$ contents of the DNAs and the cellular fatty acid profiles, Ezaki et al. proposed to transfer Peptococcus asaccharolyticus, Peptococcus indolicus, Peptococcus magnus, and Peptococcus prevotii to the genus Peptostreptococcus. Our data, in particular the DNA-rRNA homology data, indicate the relatedness of at least some of the newly proposed members of the genus Peptostreptococcus (e.g., Peptostreptococcus magnus and Peptostreptococcus prevotii; Peptostreptococcus asaccharolyticus and Peptostreptococcus indolicus). However, other peptostreptococci, such as Peptostreptococcus micros, Peptostreptococcus parvulus, and Peptostreptococcus anaerobius, show $\Delta T_{m(e)}$ values in DNArRNA hybridization studies with the former group that are too high to justify their allocation to the same genus (35). This differentiation is also supported by a comparative sequence analysis of the $16 \mathrm{~S}$ rRNAs of Peptostreptococcus asaccharolyticus ATCC $14963^{\mathrm{T}}$ and Peptostreptococcus micros ATCC 23195 (formerly called Peptococcus glycinophilus ATCC $23195^{\mathrm{T}}$ [4]). The $S_{\mathrm{AB}}$ value of 0.41 indicates that these two species are not related at the genus level (38). Final statements about the taxonomic liability of the genus Peptostreptococcus can be made only after DNA-rRNA hybridization studies with Peptostreptococcus anaerobius ATCC $27337^{\mathrm{T}}$, the type strain of the type species of the genus Peptostreptococcus, or, even better, after a comparative sequence analysis of the $16 \mathrm{~S}$ rRNA of this organism.
The murein type of gram-positive bacteria is normally a valuable taxonomic marker (33). However, we found a striking variety of murein types in the anaerobic cocci examined in this study, even in closely related strains (Table 8). Although the substitution of ornithine by lysine between Peptostreptococcus micros and Hare group IX strains may be trifling, the variety of types within the Peptostreptococcus prevotii group is remarkable. Strains NCTC 9801 and NCTC 9814 obviously belong to one species ( $D$ value, $77 \%$ ), but they have two completely different interpeptide bridges in their mureins, something that has never been observed before. Positions 1 and 3 of the peptide subunit are also different in the mureins of Peptostreptococcus asaccharolyticus DSM 20364 and NCTC 9820, which have 54\% DNA homology. The primary structure of the murein is obviously a variable marker in some gram-positive anaerobic cocci. Therefore, care has to be taken in deducing relationships solely on the basis of murein types.

\section{ACKNOWLEDGMENTS}

This work was supported by grant Schl $120 / 6$ from the Deutsche Forschungsgemeinschaft.

We are grateful to B. Williams for reading the manuscript.

\section{LITERATURE CITED}

1. Barnes, E. M., C. S. Impey, B. J. Stevens, and J. L. Peel. 1977. Streptococcus pleomorphus sp. nov.: an anaerobic Streptococcus isolated mainly from the caeca of birds. J. Gen. Microbiol. 102:45-53.

2. Brenner, D. J. 1973. Deoxyribonucleic acid reassociation in the taxonomy of enteric bacteria. Int. J. Syst. Bacteriol. 23:298307.

3. Cato, E. P. 1983. Transfer of Peptostreptococcus parvulus (Weinberg, Nativelle, and Prévot 1937) Smith 1957 to the genus Streptococcus: Streptococcus parvulus (Weinberg, Nativelle, and Prévot 1937) comb.nov., nom.rev., emend. Int. J. Syst. Bacteriol.33:82-84.

4. Cato, E. P., J. L. Johnson, D. E. Hash, and L. V. Holdeman. 1983. Synonomy of Peptococcus glycinophilus (Cardon and Barker 1946) Douglas 1957 with Peptostreptococcus micros (Prévot 1933) Smith 1957 and electrophoretic differentiation of Peptostreptococcus micros from Peptococcus magnus (Prévot 1933) Holdeman and Moore 1972. Int. J. Syst. Bacteriol. 33:207-210.

5. Colebrook, L., and R. Hare. 1933. The anaerobic streptococci associated with puerperal fever. J. Obstet. Gynaecol. Br. Emp. 40:609-629. 
6. Crosa, J. H., B. L. Williams, J. H. Jorgensen, and C. A. Evans. 1979. Comparative study of deoxyribonucleic acid homology and physiological characteristics of strains of Peptococcus saccharolyticus. Int. J. Syst. Bacteriol. 29:328-332.

7. De Ley, J. 1970. Reexamination of the association between melting point, buoyant density, and chemical base composition of deoxyribonculeic acid. J. Bacteriol. 101:738-754.

8. De Ley, J., H. Cattoir, and A. Reynaerts. 1970. The quantitative measurement of DNA hybridization from renaturation rates. Eur. J. Biochem. 12:133-142.

9. De Smedt, J., and J. De Ley. 1977. Intra- and intergeneric similarities of Agrobacterium ribosomal ribonucleic acid cistrons. Int. J. Syst. Bacteriol. 27:222-240.

10. Ezaki, T. 1982. Mole \% guanine plus cytosine of butyrateproducing anaerobic cocci and DNA/DNA relationships among them. Jpn. J. Bacteriol. 37:607-613.

11. Ezaki, T., and E. Yabuuchi. 1983. Deoxyribonucleic acid base composition and DNA/DNA hybridization studies among the four species of Peptostreptococcus Kluyver and Van Niel 1936. FEMS Microbiol. Lett. 17:197-200.

12. Ezaki, T., N. Yamamoto, K. Ninomiya, S. Suzuki, and E. Yabuuchi. 1983. Transfer of Peptococcus indolicus, Peptococcus asaccharolyticus, Peptococcus prevotii, and Peptococcus magnus to the genus Peptostreptococcus and proposal of Peptostreptococcus tetradius sp.nov. Int. J. Syst. Bacteriol. 33:683-698.

13. Fischer, S., H. Luczak, and K. H. Schleifer. 1982. Improved methods for the detection of class I and class II fructose-1,6biphosphate aldolases in bacteria. FEMS Microbiol. Lett. 15:103-108.

14. Foubert, E. L., Jr., and H. C. Douglas. 1948. Studies on the anaerobic micrococci. I. Taxonomic considerations. J. Bacteriol. 56:25-34

15. Fox, G. E., K. R. Pechman, and C. R. Woese. 1977. Comparative cataloging of $16 \mathrm{~S}$ ribosomal ribonucleic acid: molecular approach to procaryotic systematics. Int. J. Syst. Bacteriol. 27:44-57.

16. Fox, G. E., E. Stackebrandt, R. B. Hespell, J. Gibson, J. Maniloff, I. Dyer, R. S. Wolfe, W. Balch, R. Tanner, L. Magrum, L. B. Zablen, R. Blakemore, R. Gupta, K. R. Luehrsen, L. Bonen, B. J. Lewis, K. N. Chen, and C. R. Woese. 1980. The phylogeny of procaryotes. Science 209:457-463.

17. Götz, F., S. Fischer, and K. H. Schleifer. 1980. Purification and characterization of an unusually heat-stable and acid/basestable class I fructose-1,6-biphosphate aldolase from Staphylococcus aureus. Eur. J. Biochem. 108:295-301.

18. Hare, R., P. Wildy, F. S. Billett, and D. N. Twort. 1952. The anaerobic cocci: gas formation, fermentation reactions, sensitivity to antibiotics and sulphonamides. Classification. J. Hyg. 50:295-319.

19. Harris, J. W., and J. H. Brown. 1929. A clinical and bacteriological study of 113 cases of streptococci puerperal infection. Johns Hopkins Hosp. Bull. 44:1-31.

20. Hill, G. B. 1981. The anaerobic cocci, p. 1631-1658. In M. P. Starr, H. Stolp, H. G. Trüper, A. Balows, and H. G. Schlegel (ed.), The prokaryotes. Springer-Verlag, Berlin.

21. Holdeman, L. V., and W. E. C. Moore. 1974. New genus, Coprococcus, twelve new species, and emended descriptions of four previously described species of bacteria from human feces. Int. J. Syst. Bacteriol. 24:260-277.

22. Huss, V. A. R., H. Festl, and K. H. Schleifer. 1983. Studies on the spectrophotometric determination of DNA hybridization from renaturation rates. Syst. Appl. Microbiol. 4:184-192.

23. Huss, V. A. R., K. H. Schleifer, E. Lindal, O. Schwan, and C. J. Smith. 1982. Peptidoglycan type, base composition of DNA, and DNA-DNA homology of Peptococcus indolicus and Peptococcus asaccharolyticus. FEMS Microbiol. Lett. 15:285-289.

24. Kilpper, R., U. Buhl, and K. H. Schleifer. 1980. Nucleic acid homology studies between Peptococcus saccharolyticus and various anaerobic and facultative anaerobic gram-positive cocci. FEMS Microbiol. Lett. 8:205-210.
25. Kilpper-Bälz, R., and K. H. Schleifer. 1981. Transfer of Peptococcus saccharolyticus Foubert and Douglas to the genus Staphylococcus: Staphylococcus saccharolyticus (Foubert and Douglas) comb.nov. Zentralbl. Bakteriol. Parsitenkd. Infektionskr. Hyg. Abt. 1 Orig. Reihe C 2:124-331.

26. Kilpper-Bälz, R., and K. H. Schleifer. 1982. DNA-rRNA hybridization studies among staphylococci and some other grampositive bacteria. FEMS Microbiol. Lett. 10:357-362.

27. Kloos, W. E., and K. H. Schleifer. 1975. Isolation and characterization of four new species: Staphylococcus warneri, Staphylococcus capitis, Staphylococcus hominis, and Staphylococcus simulans. Int. J. Syst. Bacteriol. 25:62-79.

28. Ludwig, W., K. H. Schleifer, G. E. Fox, E. Seewaldt, and E. Stackebrandt. 1981. A phylogenetic analysis of staphylococci, Peptococcus saccharolyticus and Micrococcus mucilaginosus. J. Gen. Microbiol. 125:357-366.

29. Pace, N. R. 1973. Structure and synthesis of the ribosomal ribonucleic acid of prokaryotes. Bacteriol. Rev. 37:562-603.

30. Prévot, A. R. 1948. Manuel de classification et de determination des bacteries anaérobies. Masson, Paris.

31. Rogosa, M. 1974. Family III. Peptococcaceae, p. 517-528. In R. E. Buchanan and N. E. Gibbons (ed.), Bergey's manual of determinative bacteriology, 8th ed. The Williams \& Wilkins Co., Baltimore.

32. Schleifer, K. H. 1981. Die Klassifikation von Staphylococcus und Micrococccus. Ein Beispiel für die moderne Bakteriensystematik. Forum Mikrobiol. 5:272-278.

33. Schleifer, K. H., and O. Kandler. 1972. Peptidoglycan types of bacterial cell walls and their taxonomic implications. Bacteriol. Rev. 36:407-477.

34. Schleifer, K. H., and E. Nimmermann. 1973. Peptidoglycan types of strains of the genus Peptococcus. Arch. Mikrobiol. 93:245-258.

35. Schleifer, K. H., and E. Stackebrandt. 1983. Molecular taxonomy of prokaryotes. Annu. Rev. Microbiol. 37:143-188.

36. Stackebrandt, E., W. Ludwig, K. H. Schleifer, and H. J. Gross. 1981. Rapid cataloging of ribonuclease $T_{1}$ resistant oligonucleotides from ribosomal RNAs for phylogenetic studies. J. Mol. Evol. 17:227-236.

37. Tanner, R. S., E. Stackebrandt, G. E. Fox, and C. R. Woese. 1981. A phylogenetic analysis of Acetobacterium woodii, Clostridium barkeri, Clostridium butyricum, Clostridium lituse-burense, Eubacterium limosum, and Eubacterium tenue. Curr. Microbiol. 5:35-38.

38. Tanner, R. S., E. Stackebrandt, G. E. Fox, R. Gupta, L. J. Magrum, and C. R. Woese. 1982. A phylogenetic analysis of anaerobic eubacteria capable of synthesizing acetate from carbon dioxide. Curr. Microbiol. 7:127-132.

39. Thomas, C. G. A., and R. Hare. 1954. The classification of anaerobic cocci and their isolation in normal human beings and pathological processes. J. Clin. Pathol. 7:300-304.

40. Weiss, N. 1981. Cell wall structure of anaerobic cocci. Rev. Inst. Pasteur Lyon 14:53-59.

41. Werner, H., and G. Rintelen. 1973. Anaerobic, gram-positive cocci (Peptococcus variabilis, $P$. asaccharolyticus, $P$. prevotii and $P$. saccharolyticus) isolated from pathological material. Zentralbl. Bakteriol. Parasitenkd. Infektionskr. Hyg. Abt. 1 Orig. Reihe A 223:496-503.

42. Wittman, H. G. 1976. Structure and function and evolution of ribosomes. Eur. J. Biochem. 61:1-13.

43. Wren, M. W. D., A. W. F. Baldwin, C. P. Eldon, and P. J. Sanderson. 1977. The anaerobic culture of clinical specimens: a 14-month study. J. Med. Microbiol. 10:49-61.

44. Yankofsky, S. A., and S. Spiegelmann. 1962. The identification of the ribosomal RNA cistron by sequence complementarity. I. Specificity of complex formation. Proc. Natl. Acad. Sci. U.S.A. 48:1069-1078.

45. Yankofsky, S. A., and S. Spiegelmann. 1962. The identification of the ribosomal RNA cistron by sequence complementarity. II. Saturation of and competitive interaction at the RNA cistron. Proc. Natl. Acad. Sci. U.S.A. 48:1466-1472. 